\title{
An Alkalophilic Species of Ectothiorhodospira from a Kenyan Soda Lake
}

\author{
By WILLIAM D. GRANT, ALLAN A. MILLS* AND \\ ALLISON K. SCHOFIELD \\ Department of Microbiology, University of Leicester, Leicester LE1 7RH \\ * Department of Geology, University of Leicester
}

(Received 29 August 1978)

\begin{abstract}
An Ectothiorhodospira sp. was isolated from an alkaline mud sample from Lake Hannington, Kenya. It closely resembled Ectothiorhodospira shaposhnikovii in its ultrastructure, GC content, photosynthetic pigments, flagella position and mode of sulphur deposition, but differed in exhibiting more extreme alkalophily, the $\mathrm{pH}$ optimum being $9 \cdot 0$ to $9 \cdot 5$, and in being obligately phototrophic.
\end{abstract}

\section{INTRODUCTION}

The Gregory Rift Valley in East Africa contains a number of alkaline soda lakes, including Lakes Hannington (now known as Lake Bogoria), Elmenteita, Nakuru and Magadi (Gregory, 1921). The last is best known for the commercial exploitation of the mineral sodium sesquicarbonate (trona; $\mathrm{Na}_{2} \mathrm{CO}_{3} \cdot \mathrm{NaHCO}_{3} \cdot 2 \mathrm{H}_{2} \mathrm{O}$ ), which is dredged from the nearly dry lake (Baker, 1958). Individual lakes show total alkalinity measurements ranging from 200 to 1200 mequiv. $1^{-1}$ (Talling \& Talling, 1965; Melack \& Kilham, 1974), implying a range of $\left(\mathrm{CO}_{3}{ }^{2-}+\mathrm{HCO}_{3}{ }^{-}\right)$from 1 to $10 \%(\mathrm{w} / \mathrm{v})$, although the $\mathrm{pH}$ remains fairly constant at 11.0 for most of the soda lakes, with a higher value of 12.1 for the evaporation ponds used to extract $\mathrm{NaCl}$ at Lake Magadi. At these $\mathrm{pH}$ values $\mathrm{Na}_{2} \mathrm{CO}_{3}$ preponderates (Golterman \& Clymo, 1971; Jones et al., 1967).

The lakes have a restricted fauna and flora (Jenkin, 1929; Hecky \& Kilham, 1973) but do support large numbers of flamingoes. Although the major species of phytoplankton have been recorded and their relationships to primary biomass production have been elucidated (Melack \& Kilham, 1974), these organisms have not apparently been grown in pure culture. Moreover, the bacterial population of these lakes appears never to have been examined. Information on the microbiology of alkaline environments is scarce. There are a number of reports of organisms from extremely alkaline situations (Siegel \& Giumarro, 1965; Deal et al., 1975; Souza et al., 1974; Souza \& Deal, 1977; Isachenko, 1951) but there is much less data than that available on acidic environments (Kushner, 1971).

This paper describes the enrichment and isolation of an alkalophilic photosynthetic bacterium from Lake Hannington.

\section{METHODS}

Sample. A mud sample $(50 \mathrm{ml})$ was collected from Lake Hannington by Dr M. A. Khan, Geology Department, University of Leicester, and kept in a sealed glass container for 3 months. When opened, the mud was blackish and had a definite odour of $\mathrm{H}_{2} \mathrm{~S}$ and a $\mathrm{pH}$ of $11 \cdot 0$.

Media. The basal medium for phototrophic growth had the following composition $\left(\mathrm{g} \mathrm{l}^{-1}\right): \mathrm{NH}_{4} \mathrm{Cl}_{1} 1 \cdot 0$; $\mathrm{MgSO}_{4} .7 \mathrm{H}_{2} \mathrm{O}, 0 \cdot 4 ; \mathrm{CaCl}_{2} .2 \mathrm{H}_{2} \mathrm{O}, 0 \cdot 5 ; \mathrm{NaCl}, 0 \cdot 4 ; \mathrm{KH}_{2} \mathrm{PO}_{4}, 1 \cdot 0 ;$ sodium succinate, $2 \cdot 0$; yeast extract (Difco), $1 \cdot 0 ; \mathrm{Na}_{2} \mathrm{CO}_{3} .10 \mathrm{H}_{2} \mathrm{O}, 125 \cdot 0$; agar, 15. A solution of trace elements [containing $\left(\mathrm{g} \mathrm{l}^{-1}\right): \mathrm{ZnSO}_{4} \cdot 7 \mathrm{H}_{2} \mathrm{O}, 5 \cdot 5$; 
$\left.\mathrm{FeSO}_{4} .7 \mathrm{H}_{2} \mathrm{O}, 5 \cdot 0 ; \mathrm{Na}_{2} \mathrm{MoO}_{4} .2 \mathrm{H}_{2} \mathrm{O}, 1.0 ; \mathrm{MnCl}_{2} .4 \mathrm{H}_{2} \mathrm{O}, 5 \cdot 5 ; \mathrm{CuSO}_{4}, 1 \cdot 5 ; \mathrm{CoCl}_{2}, 1 \cdot 5\right]$ was added to the medium at $1 \mathrm{ml} \mathrm{1}^{-1}$. The normal procedure was to sterilize separately 10-fold concentrated basal medium without $\mathrm{Na}_{2} \mathrm{CO}_{3}$ and agar, a $20 \%(\mathrm{w} / \mathrm{v})$ solution of $\mathrm{Na}_{2} \mathrm{CO}_{3} .10 \mathrm{H}_{2} \mathrm{O}$, and $10 \%(\mathrm{w} / \mathrm{v})$ agar. These were then mixed together with sterile distilled water to give the required concentrations of salts and $\mathrm{Na}_{2} \mathrm{CO}_{3}$. The final $\mathrm{pH}$ of the medium was $10 \cdot 5$ to $10 \cdot 6$.

In comparative growth experiments with various hydrogen donors for phototrophic growth, the pH was adjusted to 9.8 with $\mathrm{HCl}$, sodium succinate was omitted and appropriate concentrations of sterile hydrogen donors were added. Liquid cultures containing $0.05 \%(\mathrm{w} / \mathrm{v})$ ascorbic acid were routinely employed in testing hydrogen donors. Growth was determined turbidimetrically at $650 \mathrm{~nm}$.

In comparative $\mathrm{pH}$ experiments, media containing sodium carbonate were not suitable because of the strong buffering capacity of the $\mathrm{HCO}_{3}{ }^{-} / \mathrm{CO}_{3}{ }^{2-}$ system. Liquid basal media with sodium carbonate replaced by $2 \%(\mathrm{w} / \mathrm{v}) \mathrm{NaCl}$ were used, and the $\mathrm{pH}$ was adjusted with $\mathrm{KOH}$.

Catalase. Bacteria grown on basal medium containing succinate were scraped from a plate and suspended in $3 \%(\mathrm{v} / \mathrm{v}) \mathrm{H}_{2} \mathrm{O}_{2}$. Formation of bubbles was taken as a positive reaction.

$D N A$ base composition. Bacteria were grown phototrophically in liquid basal medium for $14 \mathrm{~d}$, centrifuged at $5000 \mathrm{~g}$, and the cell pellet was frozen overnight at $-20^{\circ} \mathrm{C}$. After thawing the pellet under cold running water, DNA was extracted and purified (Hall et al., 1975). Melting points were determined spectrophotometrically in standard saline/citrate buffer. A sample of DNA from Escherichia coli was processed simultaneously. The GC content was calculated according to Marmur \& Doty (1962). A sample of the same DNA preparation was analysed by $\mathrm{CsCl}$ density gradient centrifugation.

Electron microscopy. Bacteria taken from agar plates were negatively stained by the procedure of Horne (1967). For embedding and sectioning, bacteria were fixed in $3 \%(w / v)$ glutaraldehyde for $1 \mathrm{~h}$ followed by post-fixing for $1.5 \mathrm{~h}$ in Millonig buffer $\mathrm{pH} 7 \cdot 3$ (Pease, 1964). Sections were stained with uranyl acetate and lead citrate.

Chemicals. All chemicals were analytical grade except $\mathrm{Na}_{2} \mathrm{CO}_{3} \cdot 10 \mathrm{H}_{2} \mathrm{O}$ which was laboratory grade.

\section{RESULTS}

\section{Enrichment and isolation}

A $25 \mathrm{ml}$ vial containing basal medium was inoculated with 5 to $6 \mathrm{ml}$ of the original mud sample and incubated at $30^{\circ} \mathrm{C}$ for $7 \mathrm{~d}$ under 5000 lux (fluorescent strip lighting, Philips daylight). The sample was then deep red. After a further subculture on the same medium under the same conditions, bacteria were streaked on agar medium of the same composition and incubated anaerobically using the GasPak system in transparent polycarbonate jars (GasPak Anaerobic Systems; BBL), being held upright round the walls of the chamber by an inner glass sleeve. The light intensity at the surface of the jar was 5000 lux. Colonies were restreaked several times, the purity being checked microscopically and by inoculation into Difco AC medium and Desulfovibrio medium (Abd-el-Malek \& Rizk, 1960) containing $12 \cdot 5 \%(\mathrm{w} / \mathrm{v}) \mathrm{Na}_{2} \mathrm{CO}_{3} .10 \mathrm{H}_{2} \mathrm{O}$ at $\mathrm{pH} 10 \cdot 6$.

\section{Morphology}

Bacteria were Gram-negative and pleomorphic, ranging from relatively uniform slightly curved rods on media with organic compounds as hydrogen donors to a variety of cell shapes and sizes on media containing sulphide as hydrogen donor. Spiral cells were numerous in media containing propionate. Bacteria grown on succinate were 0.6 to $0.8 \mu \mathrm{m}$ diam. and 2 to $3.5 \mu \mathrm{m}$ long. Division was by binary fission and there was no evidence of budding. In cultures grown phototrophically with sulphide as the electron donor, globules of elemental sulphur were deposited outside the bacteria (Fig. 1). There was no evidence for internal sulphur deposition although dark granules in cells were common. Bacteria grown on acetate contained granules which stained with Sudan Black (Burdon, 1946). The bacteria were motile by a tuft of polar flagella (Fig. 2). Thin sections of the cells (Fig. 3) showed a type of ultrastructure described for some non-sulphur photosynthetic bacteria (Giesbrecht \& Drews, 1966) and for sulphur photosynthetic bacteria of the genus Ectothiorhodospira (Raymond \& Sistrom, 1967; Trüper, 1968; Cherni et al., 1969).

The GC content was $61.2 \mathrm{~mol} \%\left(T_{\mathrm{m}}\right), 62.6 \mathrm{~mol} \%$ (buoyant density). 

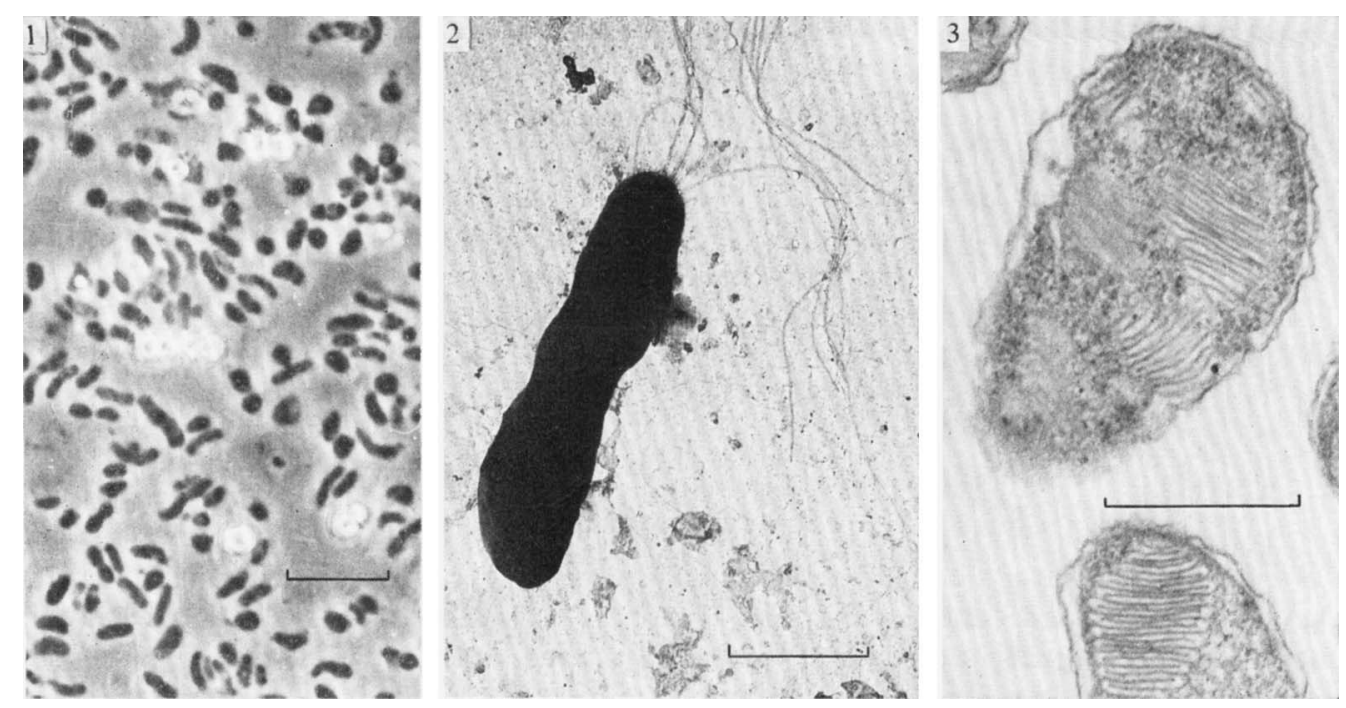

Fig. 1. Phase contrast micrograph showing sulphur deposition in sulphide-containing medium. Bar marker represents $10 \mu \mathrm{m}$.

Fig. 2. Electron micrograph showing a negatively stained flagella tuft. Bar marker represents $1 \mu \mathrm{m}$.

Fig. 3. Electron micrograph showing lamellar stacks in sectioned cells. Bar marker represents $1 \mu \mathrm{m}$.

\section{Photosynthetic pigments}

The absorption spectrum of photo-organotrophically grown whole cells, prepared on glass fibre filters by the procedure of Trüper \& Yentsch (1967), gave maxima at 375, 590 and $850 \mathrm{~nm}$ indicating the presence of bacteriochlorophyll $a$. The spectrum was similar to that described by Trüper (1968) for Ectothiorhodospira mobilis. The presence of additional absorption maxima between 435 and $535 \mathrm{~nm}$ indicated the possible presence of carotenoids of the spirilloxanthin series (Trüper, 1968). (A more detailed study of the carotenoids is in progress.)

\section{Physiology}

The organism only grew phototrophically under anaerobic conditions, either photoorganotrophically or photolithotrophically. Cultures more than 2 weeks old in liquid medium formed slimy aggregates. Some tolerance to oxygen was indicated by growth in agar to within 5 to $10 \mathrm{~mm}$ of the surface. Despite incubation periods of up to 2 months, the organism could not be induced to grow aerobically or anaerobically in the dark, or aerobically in the light or dark, under the conditions described by Uspenskaya \& Kondrat'eva (1972) for $E$. shaposhnikovii. The organism was catalase-positive.

Growth could be maintained in basal medium in the absence of yeast extract, indicating no requirement for organic growth factors. However, as the growth rate was enhanced by the inclusion of $0.1 \%$ yeast extract, this was routinely incorporated. The ability to grow without exogenously supplied vitamins is shared by E. halophila (Raymond \& Sistrom, 1969) and E. shaposhnikovii (Kondrat'eva, 1956) but not by E. halochloris (Imhoff \& Trüper, 1977) or E. mobilis (Trüper, 1968).

After incubation for 6 to $7 \mathrm{~d}$ no growth occurred in culture media below $\mathrm{pH} 7.5$ or above $\mathrm{pH} 11 \cdot 0$. The $\mathrm{pH}$ optimum was $9 \cdot 0$ to $9 \cdot 5$, and $50 \%$ of the maximum growth yield was obtained at $\mathrm{pH} 8.0$ and $10 \cdot 0$.

The temperature range for growth was 20 to $37^{\circ} \mathrm{C}$ with an optimum at $30^{\circ} \mathrm{C}$. Various hydrogen donors at the concentrations used by Trüper (1968) were tested in liquid media supplemented with $0.05 \%$ ascorbic acid. $\mathrm{Na}_{2} \mathrm{~S}, \mathrm{Na}_{2} \mathrm{~S}_{2} \mathrm{O}_{3}, \mathrm{Na}_{2} \mathrm{SO}_{3}$, acetate, propionate and 
succinate all strongly supported growth, $A_{650}$ reaching 0.8 to 1.4 after $10 \mathrm{~d}$ incubation. Elemental sulphur, malate and formate supported less growth, $A_{650}$ reaching 0.2 to 0.8 after the same period. Butyrate, citrate, benzoate, ethanol, methanol, lactate, glucose, fructose, glycerol and Casamino acids did not support growth. Molecular hydrogen was also used as an electron donor for phototrophic growth.

Neither $\mathrm{NaNO}_{3}$ nor $\mathrm{NaNO}_{2}$ could be used as nitrogen sources in place of $\mathrm{NH}_{4} \mathrm{Cl}$.

Basal medium at $\mathrm{pH} 10.6$ without $\mathrm{Na}_{2} \mathrm{CO}_{3}$ and with all other sodium salts replaced by potassium salts would not support growth. Growth was restored by the addition of either $\mathrm{NaCl}$ or $\mathrm{Na}_{2} \mathrm{CO}_{3}$. Growth occurred under these conditions at $\mathrm{NaCl}$ concentrations between 0.1 and $8 \%$ and $\mathrm{Na}_{2} \mathrm{CO}_{3} \cdot 10 \mathrm{H}_{2} \mathrm{O}$ concentrations between 0.5 and $15 \%$. Growth was markedly better in the presence of $\mathrm{Na}_{2} \mathrm{CO}_{3}$.

\section{DISCUSSION}

Like other phototrophic bacteria, Ectothiorhodospira species occur in aquatic environments where anaerobic conditions prevail. The genus is unusual amongst the purple sulphur bacteria in that members possess an extensive internal membrane system consisting of stacks of lamellae, and deposit sulphur extracellularly. The genus is also characterized by its common presence in high salt environments (Trüper, 1968), three of the four described species requiring salt for growth. Indeed two of the described species are among the few extreme halophiles outside the genera Halobacterium and Halococcus (Pfennig \& Trüper, 1974). Additionally, the original strain of E. mobilis (a moderate halophile species) was isolated from an area of high gypsum concentration in the Crimea (Pelsh, 1937) and Butlin \& Postgate (1954) may have observed members of the genus in $\mathrm{CaSO}_{4}$-saturated Libyan lake waters. Thus Ectothiorhodospira species are commonly found in situations where a variety of salts are present in high concentration.

The bacteriology of alkaline soda lakes has been little studied, although Isachenko (195I) carried out a survey of chlorous, sulphate and soda lakes of the Kulunda Steppe in the Crimea, including a microscopic examination of three alkaline soda lakes. The most alkaline of these, Tanatar III, had a predominant population of purple photosynthetic spiral bacteria which were referred to as Thiospirillum species, whereas the less alkaline lakes had a wide range of photosynthetic bacteria. It is possible that the former organisms, which were not grown in culture, could have been Ectothiorhodospira species.

The organism described here fits the generic description of Ectothiorhodospira in terms of ultrastructure, flagellation, photosynthetic pigments and sulphur deposition. Its low sodium requirement distinguishes it from three of the recognized species of Ectothiorhodospira, E. halophila and E. halochloris being extreme halophiles and E. mobilis moderately so (Imhoff \& Trüper, 1977; Trüper, 1968). The fourth recognized species, E. shaposhnikovii, like the organism described here, has a low sodium ion requirement, but requires no added salt in the medium (Cherni et al., 1969). The alkalophily shown by our organism differentiates it from all the recognized species except $E$. halochloris. Although all the species have an alkaline pH optimum, only E. halochloris exhibits a similar tolerance (Chesnokov \& Saposhnikov, 1936; Cherni et al., 1969; Imhoff \& Trüper, 1977; Kondrat'eva, 1956).

The GC content of the DNA of the organism, its lack of requirement for significant amounts of $\mathrm{NaCl}$ and general morphology indicate a possible close relationship with E. shaposhnikovii. However, the organism described here exhibits several differences from the recorded strains of this species. Ectothiorhodospira shaposhnikovii is unable to use formate but can use lactate and butyrate as hydrogen donors for phototrophic growth (Kondrat'eva, 1956), whereas the organism described here appears to be unable to utilize lactate or butyrate but does utilize formate, albeit poorly. The former organism also uses nitrate as a nitrogen source (Kondrat'eva, 1956) and can grow aerobically both in the light 
and the dark (Uspenskaya \& Kondrat'eva, 1972), whereas the organism described here could only grow phototrophically under anaerobic conditions. Our organism is more strongly alkalophilic, whereas there have not been reports of E. shaposhnikovii being isolated from alkaline environments.

Organisms of this type are the predominant phototrophic bacteria in a wide range of alkaline lakes in the Gregory Rift Valley (W. D. Grant \& B. J. Tindall, unpublished work). Recently, Imhoff \& Trüper (1977) have shown that the halophilic species E. halochloris and E. halophila occur in large numbers in alkaline saline Egyptian lakes. Ectothiorhodospira halochloris is clearly different from the organism described here since it is a halophile, contains bacteriochlorophyll $b$ and has a much lower GC ratio; but it does have the same features of alkalophily and growth enhancement in the presence of carbonate.

This work was aided by a grant (to A.A.M.) from the Research Board of the University of Leicester. The authors gratefully acknowledge the assistance of Dr C. Dow, University of Warwick, in analysing a sample of DNA by buoyant density centrifugation, and Mrs Judith Hurst for preparing the material for electron microscopy. The authors are also grateful to Dr M. A. Khan for obtaining the sample from Lake Bogoria.

\section{REFERENCES}

ABD-EL-MALEK, Y. \& RizK, S. G. (1960). Culture of Desulfovibrio desulphuricans. Nature, London 185 , $635-636$.

BAKER, B. H. (1958). Geology of the Magadi Area, Reports of the Geological Survey of Kenya, no. 42. Nairobi: Government Printer.

Burdon, K. L. (1946). Fatty material in bacteria and fungi revealed by staining dried, fixed slide preparation. Journal of Bacteriology 52, 665-678.

Butlin, K. R. \& Postgate, J. R. (1954). The microbial formation of sulphur in Cyrenaican lakes. In Biology of Deserts, pp. 112-122. Edited by J. L. Cloudsley-Thompson. London: Institute of $\mathrm{Bi}$ ology.

Cherni, N. E., Solvov'eva, Zh. V., Fedorov, V. D. \& Kondrat'Eva, E. N. (1969). Ultrastructure of cells of two species of purple sulphur bacteria. Mikrobiologiya 38, 479-484.

Chesnokov, W. A. \& Saposhnikov, D. J. (1936). The influence of $\mathrm{pH}$ on the development of the purple sulphur bacteria. Biokhimiya 1, 63-74.

Deal, P. H., SouzA, K. A. \& MACK, H. M. (1975). High $\mathrm{pH}$, ammonia toxicity, and the search for life on Jovian planets. Origins of Life 6, 561-573.

Giesbrecht, P. \& Drews, G. (1966). Über die Organisation und die makromolekulare Architektur der Thylakoide 'lebender' Bakterien. Archiv für Mikrobiologie 54, 297-330.

Golterman, H. L. \& Clymo, R. S. (1971). Methods for Chemical Analysis of Fresh Water, IBP Handbook no. 8, p. 142. Oxford and Edinburgh: Blackwell Scientific Publications.

GreGORY, J. W. (1921). The Rift Valley and Geology of East Africa. London: Seeley \& Co.

Hall, L., Turnock, G. \& Cox, B. J. (1975). Ribosomal genes in the amoebal and plasmodial forms of the slime mould Physarum polycephalum. European Journal of Biochemistry 51, 459-465.

Hecky, R. E. \& Kilham, P. (1973). Diatoms in alkaline, saline lakes: ecology and geochemical implications. Limnology and Oceanography 18, 53-71.

HORNE, R. W. (1967). Techniques for Electron Microscopy, pp. 328-355. Edited by W. Kay. Oxford: Blackwell Scientific Publications.

IMHOFF, J. F. \& TRÜPER, H. G. (1977). Ectothiorhodospira halochloris sp.nov., a new extremely halophilic phototrophic bacterium containing bacteriochlorophyll $b$. Archives of Microbiology $114,115-121$.

IsachenKo, B. L. (1951). Selected Works, vol. II, pp. 143-162. Moscow: Academy of Sciences of the Union of Soviet Socialist Republic.

Jenkin, P. M. (1929). Biology of lakes in Kenya. Nature, London 124, 574-576.

Jones, B. F., Rettig, S. L. \& Eugster, H. P. (1967). Silica in alkaline brines. Science 158, 1310-1314.

Kondrat'EVA, E. N. (1956). Assimilation of organic compounds by purple bacteria in the presence of light. Mikrobiologiya 25, 393-400.

KUSHNER, D. J. (1971). Life in extreme environments. In Chemical Evolution and the Origin of Life, pp. 485-491. Edited by R. Buvet \& C. Ponnamperuma. London: North Holland.

MARMUR, J. \& DoTY, P. (1962). Determination of the base composition of deoxyribonucleic acid from its thermal denaturation temperature. Journal of Molecular Biology 5, 109-118.

Melack, J. M. \& Kilham, P. (1974). Photosynthetic rates of phytoplankton in East African alkaline, saline lakes. Limnology and Oceanography 19, 743-755.

PeAse, D. C. (1964). Histological Techniques for Electron Microscopy. 2nd edn, p. 40. London and New York: Academic Press.

Pelsh, A. D. (1937). Photosynthetic sulphur bacteria of the eastern reservoir of Lake Sakskoe. Mikrobiologiya 6, 1090-1100.

Pfennig, N. \& Trüper, H. G. (1974). In Bergey's Manual of Determinative Bacteriology, 8th edn, 
pp. 47-48. Edited by R. E. Buchanan \& N. E. Gibbons. Baltimore: Williams \& Wilkins.

Raymond, J. C. \& Sistrom, W. R. (1967). The isolation and preliminary characterisation of a halophilic photosynthetic bacterium. Archiv für Mikrobiologie 59, 257-268.

RAYMOND, J. C. \& Sistrom, W. R. (1969). Ectothiorhodospira halophila. A new species of the genus Ectothiorhodospira. Archiv für Mikrobiologie 69, 121-126.

Siegel, S. M. \& Giumarro, C. (1965). Survival and growth of terrestrial microorganisms in ammoniarich atmospheres. Icarus 4, 37-40.

SouzA, K. A. \& DeAl, P. H. (1977). Characterization of a novel extremely alkalophilic bacterium. Journal of General Microbiology 101, 103-109.

Souza, K. A., Deal, P. H., Mack, H. M. \& TURNBILl, C. E. (1974). Growth and reproduction of microorganisms under extremely alkaline conditions. Applied Microbiology 28, 1066-1068.

Talling, J. F. \& TAlling, I. B. (1965). The chemical composition of African lake waters. Internationale Revue der gesamten Hydrobiologie und Hydrographie 50, 421-463.

TRÜPER, H. G. (1968). Ectothiorhodospira mobilis Pelsh, a photosynthetic sulfur bacterium depositing sulfur outside the cells. Journal of Bacteriology 95, 1910-1920.

TRÜPER, H. G. \& YeNTSCH, S. (1967). Use of glass fibre filters for the rapid preparation of in vitro absorption spectra of photosynthetic bacteria. Journal of Bacteriology 94, 1055-1056.

UspensKaya, V. E. \& Kondrat'Eva, E. N. (1972). Growth of the photosynthetic bacteria Ectothiorhodospira shaposhnikovii in the dark under aerobic conditions. Mikrobiologiya 41, 449-455. 